\title{
Communication
}

\section{Synthesis and Structural Characterization of (E)-4-[(2-Hydroxy-3-methoxybenzylidene)amino]butanoic Acid and Its Novel Cu(II) Complex}

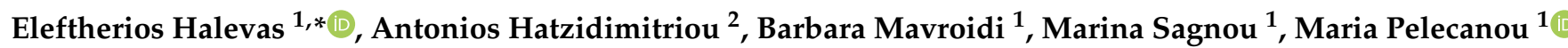 \\ and Dimitris Matiadis $1, * \mathbb{D}$ \\ 1 National Centre for Scientific Research "Demokritos", Institute of Biosciences \& Applications, \\ 15310 Athens, Greece; bmavroidi@bio.demokritos.gr (B.M.); sagnou@bio.demokritos.gr (M.S.); \\ pelmar@bio.demokritos.gr (M.P.) \\ 2 Laboratory of Inorganic Chemistry, Department of Chemistry, Aristotle University of Thessaloniki, \\ 54124 Thessaloniki, Greece; hatzidim@chem.auth.gr \\ * Correspondence: lefterishalevas@gmail.com (E.H.); dmatiadis@gmail.com or \\ matiadis@bio.demokritos.gr (D.M.); Tel.: +30-210-6503558 (D.M.)
}

Citation: Halevas, E.;

Hatzidimitriou, A.; Mavroidi, B.; Sagnou, M.; Pelecanou, M.; Matiadis, D. Synthesis and Structural

Characterization of

(E)-4-[(2-Hydroxy-3-

methoxybenzylidene)amino]butanoic Acid and Its Novel $\mathrm{Cu}$ (II) Complex. Molbank 2021, 2021, 1179.

https://doi.org/10.3390/M1179

Academic Editor: Kristof Van Hecke Received: 23 December 2020

Accepted: 2 January 2021

Published: 6 January 2021

Publisher's Note: MDPI stays neutral with regard to jurisdictional clai$\mathrm{ms}$ in published maps and institutional affiliations.

Copyright: (C) 2021 by the authors. Licensee MDPI, Basel, Switzerland. This article is an open access article distributed under the terms and conditions of the Creative Commons Attribution (CC BY) license (https:// creativecommons.org/licenses/by/ $4.0 /)$.

\begin{abstract}
A novel $\mathrm{Cu}(\mathrm{II})$ complex based on the Schiff base obtained by the condensation of orthovanillin with gamma-aminobutyric acid was synthesized. The compounds are physico-chemically characterized by elemental analysis, HR-ESI-MS, FT-IR, and UV-Vis. The complex and the Schiff base ligand are further structurally identified by single crystal $\mathrm{X}$-ray diffraction and ${ }^{1} \mathrm{H}$ and ${ }^{13} \mathrm{C}-\mathrm{NMR}$, respectively. The results suggest that the Schiff base are synthesized in excellent yield under mild reaction conditions in the presence of glacial acetic acid and the crystal structure of its $\mathrm{Cu}$ (II) complex reflects an one-dimensional polymeric compound. The molecular structure of the complex consists of a $\mathrm{Cu}$ (II) ion bound to two singly deprotonated Schiff base bridging ligands that form a $\mathrm{CuN}_{2} \mathrm{O}_{4}$ chelation environment, and a coordination sphere with a disordered octahedral geometry.
\end{abstract}

Keywords: imine; Schiff base; X-ray crystallographic analysis; $\mathrm{Cu}(\mathrm{II})$ complex; gamma-amino acid

\section{Introduction}

Schiff bases have attracted intensive scientific interest mainly because of their ease of preparation, diverse structural and physico-chemical characteristics, metal binding affinity, pharmacological and physiological properties. They have been extensively used as ligands in the coordination chemistry of main group and transition metal ions. These compounds and their metal complexes have been proved very effective as catalysts in several biological systems, dyes, polymers, and as bioactive agents in the pharmaceutical and medicinal fields presenting exceptional antibacterial, antioxidant, antifungal, anticancer, antidiabetic, and diuretic properties [1-5].

A well-established sub-category of Schiff bases is the amino acid-based Schiff bases. The incorporation of amino acids in the Schiff base structure enables the design of ligands with enhanced chirality and multidentate functionality [6]. Several literature reports confirm the involvement of amino acid Schiff base complexes in a variety of chemical and biological processes such as the catalysis of transamination, carboxylation and racemization reactions [7], the oxidation of sulfides and olefins, in polymerization processes, and the decomposition of $\mathrm{H}_{2} \mathrm{O}_{2}$ [8]. Moreover, it has been proved that amino acid Schiff base complexes can be used as radiotracers in nuclear medicine [9], and as anticancer and antibacterial agents [10,11].

Until today, a large number of crystallographically characterized metal complexes of alpha- and beta-amino acid Schiff bases have been reported in the literature [12,13]. However, only a few metal complexes of Schiff bases derived from gamma-amino acids have been structurally characterized via X-ray crystallography [14]. Herein, we report the synthesis 
of a novel $\mathrm{Cu}(\mathrm{II})$ complex based on a new Schiff base obtained by the condensation of orthovanillin with gamma-aminobutyric acid. The compounds have been physico-chemically characterized by elemental analysis, HR-ESI-MS, FT-IR, and UV-Visible spectrophotometry. The complex and the Schiff base ligand have been further structurally identified by single crystal X-ray and ${ }^{1} \mathrm{H}$ and ${ }^{13} \mathrm{C}-\mathrm{NMR}$, respectively.

\section{Results and Discussion}

\subsection{Synthesis}

The Schiff base 3 was synthesized in one step by mixing equimolar quantities of ortho-vanillin 1 and gamma-aminobutyric acid 2 in the minimum amount of refluxing $\mathrm{MeOH}$ (Scheme 1). After filtration and washing, product 3 was obtained in very good yield $(76 \%)$. In order to further improve the yield of the reaction, the application of (a) glacial acetic acid as a mild acidic agent appropriate for such couplings $[15,16]$, (b) sulfuric acid as a dehydrating acid [17], and (c) piperidine as one the most commonly used bases for Schiff base formation of vanillin derivatives [18] was explored (Table 1). Piperidine seemed to partially "quench" the coupling, leading to lower yields, even after forcing the product precipitation. The presence of glacial acetic acid increased the yield of the reaction to almost quantitative $(86 \%)$, whereas using concentrated sulfuric acid was proved to be unsuccessful.<smiles>COc1cccc(C=O)c1O</smiles>

1<smiles>NCCCC(=O)O</smiles>

2

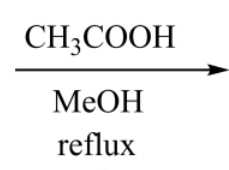

$2 \mathrm{~h}$<smiles>COc1cccc(/C=N/CCCC(=O)O)c1O</smiles>

$3(86 \%)$

Scheme 1. Synthesis of (E)-4-((2-hydroxy-3-methoxybenzylidene)amino)butanoic acid (3).

Table 1. Optimization of the reaction conditions regarding the additive ${ }^{\text {a }}$<smiles>COc1cccc(C=O)c1O</smiles>

1<smiles>NCCCC(=O)O</smiles>

2<smiles>COc1cccc(/C=N/CCCC(=O)O)c1O</smiles>
$3(86 \%)$

\begin{tabular}{ccc}
\hline Entry & Additive & Yield (\%) $^{\mathbf{b}}$ \\
\hline 1 & none & 76 \\
2 & $\mathrm{CH}_{3} \mathrm{COOH}$ & 86 \\
3 & $\mathrm{H}_{2} \mathrm{SO}_{4}{ }^{\mathrm{c}}$ & trace amount \\
4 & piperidine & $58^{\mathrm{c}}$ \\
\hline
\end{tabular}

a The reactions were carried out using $1.0 \mathrm{mmol}$ of each starting compound and 2 drops of each additive $(0.1 \mathrm{~mL})$, under reflux for $2 \mathrm{~h} .{ }^{\mathrm{b}}$ Isolated yield after concentration of the solvent to $2 / 3$ of its volume. ${ }^{\mathrm{c}}$ Isolated yield, after further concentration of the solvent to $1 / 3$ of its volume and storage at $-18^{\circ} \mathrm{C}$ for $48 \mathrm{~h}$

The structure and purity of compound 3 was confirmed by ${ }^{1} \mathrm{H}$ and ${ }^{13} \mathrm{C}-\mathrm{NMR}$ (Supplementary Information, Figures S1-S6). As expected, the methylene protons of the amino acid unit appeared in the aliphatic region of the ${ }^{1} \mathrm{H}-\mathrm{NMR}$ spectrum. $\mathrm{H}-4$ protons (see Figure 1A numbering) were shifted downfield at $3.60 \mathrm{ppm}$ because of the nitrogen atom. The aromatic protons appeared according to the standard shift and splitting pattern of 1,2,3-trisubstituted benzene rings at $6.79,7.00$, and $7.02 \mathrm{ppm}$. The ${ }^{13} \mathrm{C}-\mathrm{NMR}$ spectrum is in good agreement with the structure and reported data $[19,20]$. The low-field signals of azomethine, C-7 and carboxylic carbons were assigned by 2D-NMR experiments (Supplementary Information, Figures S3-S6) at 166.2, 151.9, and 174.0 ppm, respectively. 
NOESY experiment demonstrated that 3 has the same configuration with the coordinated ligand, since a signal corresponding to azomethine proton ( $8.53 \mathrm{ppm}$ ) and $\mathrm{H}-9$ of the ring $(7.02 \mathrm{ppm})$ proximity was detected, thus proving the expected $E$-configuration.

Under standard NMR experiment conditions $\left(0.05 \mathrm{M}\right.$ in DMSO- $\left.d_{6}\right)$ we were not able to distinguish the phenolic $\mathrm{OH}$ proton from the carboxylic $\mathrm{OH}$ proton, due to broadening of these peaks, leading to the absence of 2D signals. Even by modifying the conditions (concentration, temperature, and/or solvent) we did not observe the desired peak sharpening or appearance of any additional clarifying 2D signals. Since the structural elucidation by NMR of similar Schiff bases systems incorporating an ortho-hydroxy phenyl unit have been reported in the literature $[19,20]$, the broad peak at $12.2 \mathrm{ppm}$ was assigned to the carboxylic proton, whereas the lower-field broad peak at $13.7 \mathrm{ppm}$ was assigned to the deshielded phenolic proton.

For the synthesis of the heteroleptic Cu(II)-Schiff base complex (4) (Scheme 2) a thorough exploration of the experimental conditions regarding solvent system, $\mathrm{pH}$, temperature, metal:ligand stoichiometry, and crystallization process was performed. Subsequently, complex 4 was synthesized from the reaction of $\mathrm{Cu}\left(\mathrm{NO}_{3}\right)_{2} \cdot 3 \mathrm{H}_{2} \mathrm{O}$ with the Schiff base in $\mathrm{MeOH}$ at $60^{\circ} \mathrm{C}$ under reflux conditions, in the presence of sodium hydroxide $(\mathrm{NaOH})$. The overall stoichiometric reaction leading to complex 4 is shown schematically below:

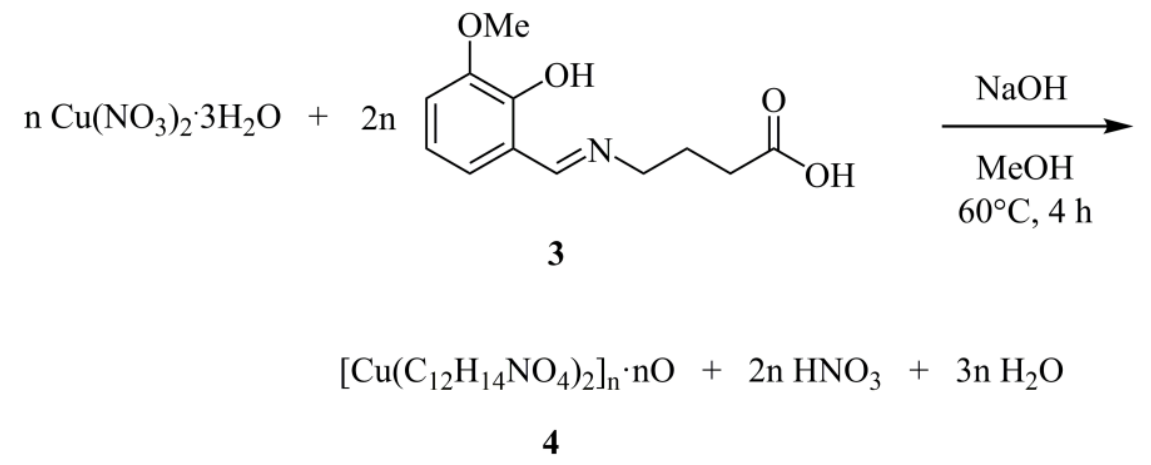

Scheme 2. Stoichiometric reaction of the heteroleptic $\mathrm{Cu}$ (II)-Schiff base complex (4).

The reaction mixture was left to evaporate slowly at room temperature. Dark green crystalline material emerged in the reaction described above, the analytical composition of which was consistent with the formulation in complex 4. Positive identification of the crystalline product was achieved by elemental analysis, FT-IR, HR-ESI-MS, and X-ray crystallographic analysis of isolated single crystals from complex 4.

Both compounds are stable in air for fairly long periods of time. They readily dissolve in $\mathrm{H}_{2} \mathrm{O}$, methanol (MeOH), dimethylacetamide (DMA), dimethyl sulfoxide (DMSO), and dimethylformamide (DMF) and are insoluble in acetone, acetonitrile, and dichloromethane at room temperature.

\subsection{Description of X-ray Crystallographic Structure}

The X-ray crystal structure of 4 reveals a discrete solid-state lattice. The molecular structure of $\mathbf{2}$ is given in Figure 1A; selected bond distances and angles are listed in Table 2. Complex 4 crystallizes in the monoclinic space group $\mathrm{C} 2 / c$. The crystal structure reflects an one-dimensional polymeric compound forming infinite chains along the $c$ crystallographic axis. The unit cell contains four mononuclear $\left[\mathrm{Cu}\left(\mathrm{C}_{12} \mathrm{H}_{14} \mathrm{NO}_{4}\right)_{2}\right]$ monomeric complex units and half of a badly disordered lattice $\mathrm{MeOH}$ molecule. The molecular structure of the monomer 4 consists of a $\mathrm{Cu}$ (II) ion bound to two singly deprotonated Schiff base bridging ligands which coordinate through their deprotonated phenolato oxygen atom, the imino nitrogen atom, and the double bonded oxygen atoms of the protonated carboxylic acid moieties from two neighboring molecules, thereby giving rise to a $\mathrm{Cu}^{\mathrm{II}} \mathrm{N}_{2} \mathrm{O}_{4}$ chelation environment, and a coordination sphere reflecting a disordered octahedral geometry 
(Figure 1A). The Cu-N bond lengths are 2.005(2) $\AA$ whereas the $\mathrm{Cu}-\mathrm{O}$ bond lengths are in the range between 1.9272(16) and 2.6167(19) $\AA$. These values are very similar to the related bond distances reported in the literature [21]. Intermolecular hydrogen-bonding interactions arise between the deprotonated phenolic oxygen atoms and the protonated oxygen atoms of the carboxylic groups from the neighboring monomeric complex units enforcing the polymeric chains formation and resulting in the final 1D crystal lattice (Figure 1B, Supplementary Information Table S1).

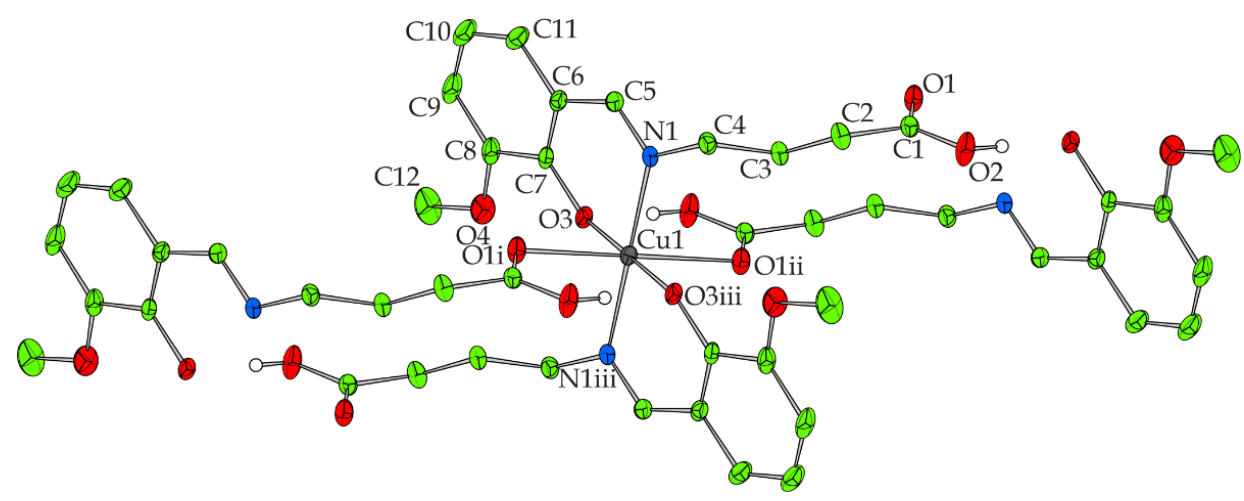

(A)

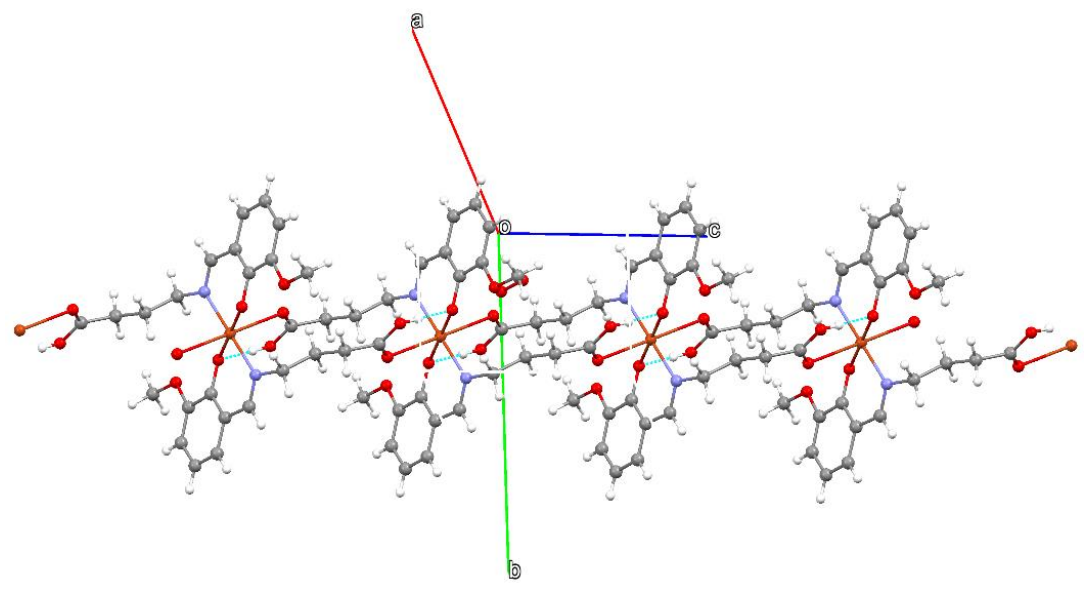

(B)

Figure 1. (A) The fully coordinated monomeric complex unit of 4 . Carbon group hydrogen atoms and lattice solvent molecule have been omitted. (B) Part of the polymeric chain of $\mathbf{4}$ and hydrogen bonding interactions (light blue dotted lines).

Table 2. Bond lengths $[\AA]$ and angles $\left[{ }^{\circ}\right]$ for 4 .

\begin{tabular}{cccc}
\hline \multicolumn{5}{c}{ Bond Lengths (Å) } \\
\hline $\mathrm{Cu}(1)-\mathrm{O}(1)^{\mathrm{i}}$ & $2.6167(19)$ & $\mathrm{O}(4)-\mathrm{C}(12)$ & $1.429(3)$ \\
$\mathrm{Cu}(1)-\mathrm{O}(1)^{\mathrm{ii}}$ & $2.6167(19)$ & $\mathrm{O}(5)-\mathrm{O}(5) \mathrm{iv}$ & $1.449(5)$ \\
$\mathrm{Cu}(1)-\mathrm{N}(1)^{\mathrm{iii}}$ & $2.005(2)$ & $\mathrm{C}(1)-\mathrm{C}(2)$ & $1.505(4)$ \\
$\mathrm{Cu}(1)-\mathrm{O} 3^{\mathrm{iii}}$ & $1.9272(16)$ & $\mathrm{C}(2)-\mathrm{C}(3)$ & $1.514(3)$ \\
$\mathrm{Cu}(1)-\mathrm{N}(1)$ & $2.005(2)$ & $\mathrm{C}(3)-\mathrm{C}(4)$ & $1.510(3)$ \\
$\mathrm{Cu}(1)-\mathrm{O}(3)$ & $1.9272(16)$ & $\mathrm{C}(5)-\mathrm{C}(6)$ & $1.443(4)$ \\
$\mathrm{N}(1)-\mathrm{C}(4)$ & $1.476(3)$ & $\mathrm{C}(6)-\mathrm{C}(7)$ & $1.392(4)$ \\
$\mathrm{N}(1)-\mathrm{C}(5)$ & $1.282(3)$ & $\mathrm{C}(6)-\mathrm{C}(11)$ & $1.406(4)$ \\
$\mathrm{O}(1)-\mathrm{C}(1)$ & $1.203(3)$ & $\mathrm{C}(7)-\mathrm{C}(8)$ & $1.421(3)$ \\
$\mathrm{O}(2)-\mathrm{C}(1)$ & $1.308(3)$ & $\mathrm{C}(8)-\mathrm{C}(9)$ & $1.389(5)$ \\
$\mathrm{O}(3)-\mathrm{C}(7)$ & $1.325(3)$ & $\mathrm{C}(9)-\mathrm{C}(10)$ & $1.373(5)$ \\
$\mathrm{O}(4)-\mathrm{C}(8)$ & $1.363(4)$ & $\mathrm{C}(10)-\mathrm{C}(11)$ & $1.354(5)$ \\
\hline
\end{tabular}


Table 2. Cont.

\begin{tabular}{|c|c|c|c|}
\hline \multicolumn{4}{|c|}{ Angles $\left(^{\circ}\right)$} \\
\hline $\mathrm{O}(1)^{\mathrm{i}}-\mathrm{Cu}(1)-\mathrm{O}(1)^{\mathrm{ii}}$ & 180 & $\mathrm{C}(8)-\mathrm{O}(4)-\mathrm{C}(12)$ & $117.5(3)$ \\
\hline $\mathrm{O}(1)^{\mathrm{i}}-\mathrm{Cu}(1)-\mathrm{N}(1){ }^{\mathrm{iii}}$ & $93.65(7)$ & $\mathrm{O}(2)-\mathrm{C}(1)-\mathrm{O}(1)$ & $122.9(2)$ \\
\hline $\mathrm{O}(1){ }^{\mathrm{ii}}-\mathrm{Cu}(1)-\mathrm{N}(1){ }^{\mathrm{iii}}$ & $86.35(7)$ & $\mathrm{O}(2)-\mathrm{C}(1)-\mathrm{C}(2)$ & $114.0(2)$ \\
\hline $\mathrm{O}(1)^{\mathrm{i}}-\mathrm{Cu}(1)-\mathrm{O}(3)^{\mathrm{iii}}$ & $83.34(7)$ & $\mathrm{O}(1)-\mathrm{C}(1)-\mathrm{C}(2)$ & $123.1(2)$ \\
\hline $\mathrm{O}(1)^{\mathrm{ii}}-\mathrm{Cu}(1)-\mathrm{O}(3){ }^{\mathrm{iii}}$ & $96.66(7)$ & $C(1)-C(2)-C(3)$ & $112.2(2)$ \\
\hline $\mathrm{N}(1){ }^{\mathrm{iii}}-\mathrm{Cu}(1)-\mathrm{O}(3){ }^{\mathrm{iii}}$ & $90.23(8)$ & $C(2)-C(3)-C(4)$ & $112.8(2)$ \\
\hline $\mathrm{O}(1){ }^{\mathrm{i}}-\mathrm{Cu}(1)-\mathrm{N}(1)$ & $86.35(7)$ & $\mathrm{C}(3)-\mathrm{C}(4)-\mathrm{N}(1)$ & $110.5(2)$ \\
\hline $\mathrm{O}(1){ }^{\mathrm{ii}}-\mathrm{Cu}(1)-\mathrm{N}(1)$ & $93.65(7)$ & $N(1)-C(5)-C(6)$ & $126.7(2)$ \\
\hline $\mathrm{N}(1){ }^{\mathrm{iii}}-\mathrm{Cu}(1)-\mathrm{N}(1)$ & 180 & $C(5)-C(6)-C(7)$ & $121.9(2)$ \\
\hline $\mathrm{O}(3){ }^{\mathrm{iii}}-\mathrm{Cu}(1)-\mathrm{N}(1)$ & $89.77(8)$ & $C(5)-C(6)-C(11)$ & $117.6(3)$ \\
\hline $\mathrm{O}(1){ }^{\mathrm{i}}-\mathrm{Cu}(1)-\mathrm{O}(3)$ & $96.66(7)$ & $C(7)-C(6)-C(11)$ & $120.5(3)$ \\
\hline $\mathrm{O}(1){ }^{\mathrm{ii}}-\mathrm{Cu}(1)-\mathrm{O}(3)$ & $83.34(7)$ & $\mathrm{C}(6)-\mathrm{C}(7)-\mathrm{O}(3)$ & $123.9(2)$ \\
\hline $\mathrm{N}(1){ }^{\mathrm{ii}}-\mathrm{Cu}(1)-\mathrm{O}(3)$ & $89.77(8)$ & $C(6)-C(7)-C(8)$ & $118.2(3)$ \\
\hline $\mathrm{O}(3){ }^{\mathrm{iii}}-\mathrm{Cu}(1)-\mathrm{O}(3)$ & 180 & $\mathrm{O}(3)-\mathrm{C}(7)-\mathrm{C}(8)$ & $117.8(3)$ \\
\hline $\mathrm{N}(1)-\mathrm{Cu}(1)-\mathrm{O}(3)$ & $90.23(8)$ & $\mathrm{C}(7)-\mathrm{C}(8)-\mathrm{O}(4)$ & $114.6(3)$ \\
\hline $\mathrm{Cu}(1)-\mathrm{N}(1)-\mathrm{C}(4)$ & $120.85(16)$ & $C(7)-C(8)-C(9)$ & $119.2(3)$ \\
\hline $\mathrm{Cu}(1)-\mathrm{N}(1)-\mathrm{C}(5)$ & $122.71(18)$ & $\mathrm{O}(4)-\mathrm{C}(8)-\mathrm{C}(9)$ & $126.2(3)$ \\
\hline $\mathrm{C}(4)-\mathrm{N}(1)-\mathrm{C}(5)$ & $116.4(2)$ & $C(8)-C(9)-C(10)$ & $121.5(3)$ \\
\hline $\mathrm{Cu}(1)^{\mathrm{v}}-\mathrm{O}(1)-\mathrm{C}(1)$ & $124.19(17)$ & $C(9)-C(10)-C(11)$ & $120.1(3)$ \\
\hline $\mathrm{Cu}(1)-\mathrm{O}(3)-\mathrm{C}(7)$ & $123.43(16)$ & $C(6)-C(11)-C(10)$ & $120.5(3)$ \\
\hline $\mathrm{Cu}(1)-\mathrm{O}(1)^{\mathrm{i}}$ & $2.6167(19)$ & $\mathrm{O}(4)-\mathrm{C}(12)$ & $1.429(3)$ \\
\hline $\mathrm{Cu}(1)-\mathrm{O}(1){ }^{\mathrm{ii}}$ & $2.6167(19)$ & $\mathrm{O}(5)-\mathrm{O}(5){ }^{\mathrm{iv}}$ & 1.449 (5) \\
\hline
\end{tabular}

Symmetry codes: ${ }^{i} \mathrm{x}, \mathrm{y}, \mathrm{z}-1{ }^{\text {ii }}-\mathrm{x}+3 / 2,-\mathrm{y}+3 / 2,-\mathrm{z}+3$; iii $^{\mathrm{ii}} \mathrm{x}+3 / 2,-\mathrm{y}+3 / 2,-\mathrm{z}+2{ }^{\text {iv }}-\mathrm{x}+1, \mathrm{y},-\mathrm{z}+1 / 2$; ${ }^{v} \mathrm{x}, \mathrm{y}, \mathrm{z}+1$.

\subsection{FT-IR Spectroscopy}

The FT-IR spectrum of the Schiff base 3 (Supplementary Information, Figure S7) shows a weak band at $3419 \mathrm{~cm}^{-1}$, characteristic of the $v(\mathrm{OH})$ vibrations [22], which disappears in the spectrum of complex 4 (Supplementary Information, Figure S7), indicating deprotonation of the $\mathrm{OH}$ group upon binding with the $\mathrm{Cu}(\mathrm{II})$ ion. The $v(\mathrm{C}=\mathrm{N})$ vibrations are observed at $1643 \mathrm{~cm}^{-1}$ for Schiff base 3 and at $1598 \mathrm{~cm}^{-1}$ for complex 4, respectively. This lowering of resonance frequency by $45 \mathrm{~cm}^{-1}$ for the $\mathrm{C}=\mathrm{N}$ vibration clearly reveals the coordination of the $\mathrm{Cu}(\mathrm{II})$ ion with the imine nitrogen. Moreover, both spectra show broad absorption bands at about $3068-2758 \mathrm{~cm}^{-1}$ and $3089-2818 \mathrm{~cm}^{-1}$, respectively, which are assigned to the $v(\mathrm{C}-\mathrm{H})$ stretching vibrations of the aromatic moieties. The absorption bands located at $526 \mathrm{~cm}^{-1}$ and $465 \mathrm{~cm}^{-1}$ in the spectrum of complex 4 can be assigned to the $v(\mathrm{Cu}-\mathrm{O})$ and $v(\mathrm{Cu}-\mathrm{N})$ vibrations, respectively.

\subsection{UV-Vis Spectroscopy}

The UV-Vis spectra of the Schiff base 3 and complex 4 were recorded in $\mathrm{MeOH}$ at a concentration of $10^{-5} \mathrm{M}$ (Figure 2). The electronic absorption spectrum of the Schiff base shows an absorption band at $293 \mathrm{~nm}$ and $417 \mathrm{~nm}$ that can be assigned to the $\pi \rightarrow \pi^{*}$ transitions in the aromatic ring and $n \rightarrow \pi^{*}$ transitions of the imine moiety, respectively. In the spectrum of 4, both absorption bands present significant hypsochromic and hyperchromic shifts compared to the free Schiff base, which can be attributed to the increased conjugation of the $\mathrm{Cu}$ (II)-Schiff base system. More specifically, the absorption band, indicative of the $\pi \rightarrow \pi^{*}$ transitions, appears at $274 \mathrm{~nm}$ whereas the absorption band that arises from the $n \rightarrow \pi^{*}$ transitions is located at $381 \mathrm{~nm}$. No $d \rightarrow d$ transitions were observed in the spectrum of 4 , potentially because of the low concentration $\left(10^{-5} \mathrm{M}\right)$ of the solution. However, additional measurements at a higher concentration $\left(10^{-3} \mathrm{M}\right)$ (inset graph in Figure 2) showed a broad absorption band at $682 \mathrm{~nm}$, indicative of $d \rightarrow d$ transitions. 


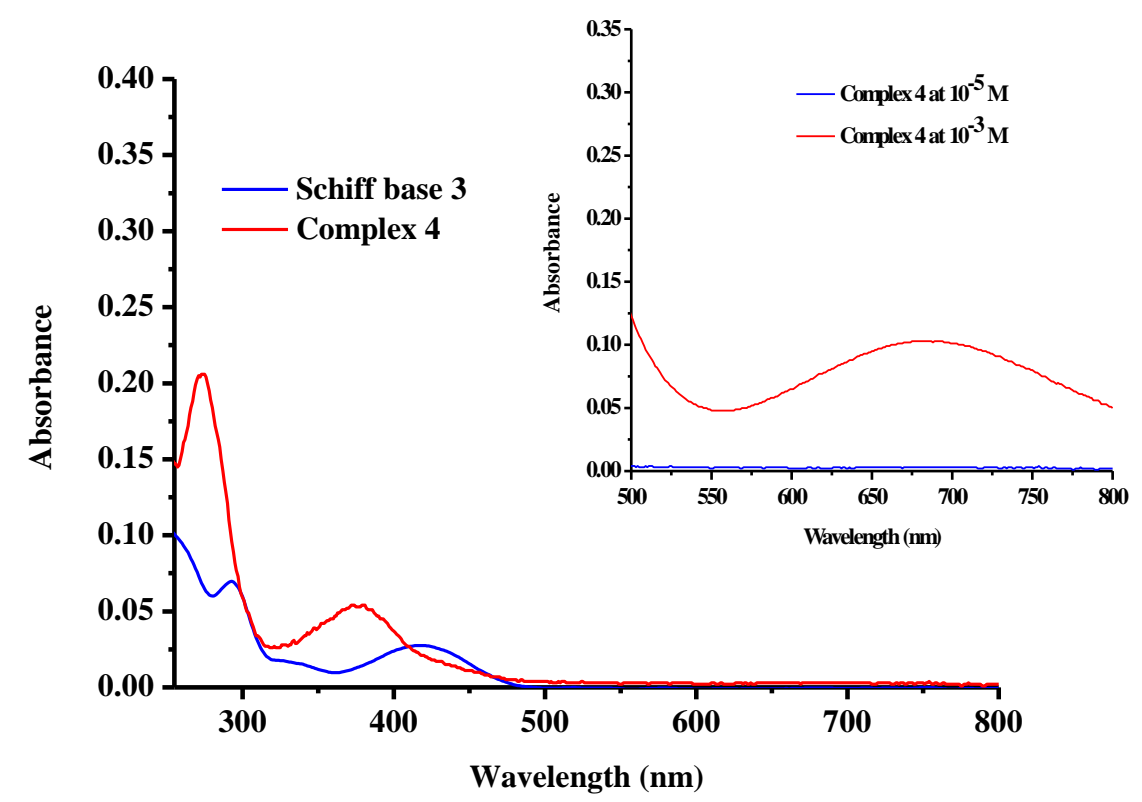

Figure 2. UV-Vis spectra of the Schiff base 3 (blue line) and complex 4 (red line) in $\mathrm{MeOH}$ at a concentration of $10^{-5} \mathrm{M}$. The inset graph presents the $\mathrm{d}-\mathrm{d}$ transitions observed in $\mathrm{MeOH}$ at a concentration of $10^{-3} \mathrm{M}$.

\section{Materials and Methods}

The following starting materials were purchased from commercial sources (Sigma, Fluka, St. Louis, MO, USA) and were used without further purification: Gamma-aminobutyric acid, ortho-vanillin, copper nitrate trihydrate $\left[\mathrm{Cu}\left(\mathrm{NO}_{3}\right)_{2} \cdot 3 \mathrm{H}_{2} \mathrm{O}\right]$, and sodium hydroxide $(\mathrm{NaOH})$ pellets. Solvents: ethanol $(\mathrm{EtOH})$, methanol $(\mathrm{MeOH})$. The isolated and dried under vacuum at room temperature compounds are air-stable. Fourier transform-infrared (FT-IR) spectra were recorded on a Perkin Elmer 1760X spectrometer (Perkin-Elmer, San Francisco, CA, USA). A ThermoFinnigan Flash EA 1112 CHNS elemental analyzer (Waltham, MA, USA) was used for the simultaneous determination of carbon, hydrogen, and nitrogen (\%). The analyzer operation is based on the dynamic flash combustion of the sample (at $180{ }^{\circ} \mathrm{C}$ ) followed by reduction, trapping, complete GC separation, and detection of the products. The instrument is fully automated and controlled by PC via the Eager 300 dedicated software (Thermo Fischer, Waltham, MA, USA). High resolution electrospray spray ionization mass spectra (HR-ESI-MS) of the Schiff base (1) and its $\mathrm{Cu}$ (II) complex (2) were obtained on UHPLC LC-MSn Orbitrap Velos-Thermo instrument (Thermo Scientific; Bremen, Germany) in the Institute of Biology, Medicinal Chemistry and Biotechnology of the National Hellenic Research Foundation. NMR spectra were recorded with a Bruker Avance $500 \mathrm{MHz}$ spectrometer (Bruker, Rheinstetten, Germany) operating at $500 \mathrm{MHz}\left({ }^{1} \mathrm{H}\right)$ and $125 \mathrm{MHz}$ $\left({ }^{13} \mathrm{C}\right)$. Chemical shifts are reported in ppm relative to DMSO- $d_{6}\left({ }^{1} \mathrm{H}: \delta=2.50 \mathrm{ppm},{ }^{13} \mathrm{C}\right.$ : $\delta=39.52 \pm 0.06 \mathrm{ppm})$. NMR spectra assignments follow the numbering of the crystallographic analysis (Figure 1A). UV-Visible (UV-Vis) measurements were carried out on a Hitachi U2001 spectrophotometer (Hitachi, Tokyo, Japan) in the range from 200 to $800 \mathrm{~nm}$.

\subsection{Synthesis}

3.1.1. (E)-4-[(2-Hydroxy-3-methoxybenzylidene)amino]butanoic Acid (3)

Ortho-vanillin 1 (152 mg, $1.0 \mathrm{mmol}$ ) dissolved in $0.5 \mathrm{~mL} \mathrm{MeOH}$, was added in a refluxing methanolic solution $(6.5 \mathrm{~mL})$ of gamma-aminobutyric acid $2(103 \mathrm{mg}, 1.0 \mathrm{mmol})$. Two drops of glacial acetic acid $(0.1 \mathrm{~mL}, 1.75 \mathrm{mmol})$ were added and the resulting clear solution was stirred for $2 \mathrm{~h}$. Upon completion of the reaction, the solvent was allowed to distill off by removing the reflux apparatus until reaching approximately $2 / 3$ of its volume. Then, the solution was cooled to room temperature to afford the product as crystal needles. The bright yellow product $(204 \mathrm{mg}, 0.86 \mathrm{mmol}, 86 \%$ ) was filtered, washed once with a small 
volume of ice-cold $\mathrm{MeOH}$ and dried under vacuum. ${ }^{1} \mathrm{H}-\mathrm{NMR}$ (500 MHz, DMSO- $d_{6}$ ): 1.86 (quint, $J=7.0 \mathrm{~Hz}, 2 \mathrm{H}, \mathrm{H}-3), 2.29(\mathrm{t}, J=7.0 \mathrm{~Hz}, 2 \mathrm{H}, \mathrm{H}-2), 3.60(\mathrm{t}, J=7.0 \mathrm{~Hz}, 2 \mathrm{H}, \mathrm{H}-4), 3.77$ $(\mathrm{s}, 3 \mathrm{H}, \mathrm{OMe}), 6.79(\mathrm{t}, J=7.9 \mathrm{~Hz}, 1 \mathrm{H}, \mathrm{H}-10), 7.00(\mathrm{t}, J=7.9 \mathrm{~Hz}, 1 \mathrm{H}, \mathrm{H}-11), 7.02(\mathrm{t}, J=7.9 \mathrm{~Hz}$, 1H, H-9), 8.53 (s, 1H, H-5), 12.2 (br, $1 \mathrm{H}, \mathrm{COOH}), 13.7$ (br, $1 \mathrm{H}, \mathrm{OH}) \mathrm{ppm} ;{ }^{13} \mathrm{C}-\mathrm{NMR}(125 \mathrm{MHz}$, DMSO- $\left.d_{6}\right)$ : 25.8 (C-3), 31.2 (C-2), 55.7 (OMe), 57.0 (C-4), 114.7 (C-9), 117.5 (C-10), 118.2 (C-6), 123.1 (H-11), 148.1 (C-8), 151.9 (C-7), 166.2 (C-5), 174.0 (COOH) ppm; Anal. Calcd for 1, $\mathrm{C}_{12} \mathrm{H}_{15} \mathrm{NO}_{4}$ : C, 60.75; H, 6.37; N, 5.90. Found: C, 60.69; H, 6.31; N, 5.94. HR-ESI-MS (positive mode), calcd. for $\left[\left(\mathrm{C}_{12} \mathrm{H}_{15} \mathrm{NO}_{4}\right)+\mathrm{H}\right]^{+} m / z=238.1079$, found $m / z=238.1076$.

\subsubsection{Synthesis of $\left[\mathrm{Cu}\left(\mathrm{C}_{12} \mathrm{H}_{14} \mathrm{NO}_{4}\right)_{2}\right]_{\mathrm{n}} \cdot \mathrm{nO}(4)$}

To a solution of ortho-vanillin $\mathbf{1}(0.15 \mathrm{~g}, 1.0 \mathrm{mmol})$ in $\mathrm{MeOH}(10 \mathrm{~mL})$ gamma-aminobutyric acid $2(0.10 \mathrm{~g}, 1.0 \mathrm{mmol})$ was added under stirring. The resulting yellow solution was refluxed for two hours at $60^{\circ} \mathrm{C}$ under continuous stirring and then cooled to room temperature. Subsequently, a solution of $\mathrm{Cu}\left(\mathrm{NO}_{3}\right)_{2} \cdot 3 \mathrm{H}_{2} \mathrm{O}(0.12 \mathrm{~g}, 0.5 \mathrm{mmol})$ in $\mathrm{MeOH}(10 \mathrm{~mL})$ was added under continuous stirring. The resulting clear, green reaction mixture was refluxed for an additional $2 \mathrm{~h}$ at $60{ }^{\circ} \mathrm{C}$ and then cooled to room temperature. To that, $\mathrm{NaOH}(0.04 \mathrm{~g}, 1 \mathrm{mmol})$ was added under continuous stirring. The resulting homogeneous dark green reaction mixture was refluxed at $60{ }^{\circ} \mathrm{C}$ for an additional $2 \mathrm{~h}$ and then cooled to room temperature. Subsequently, the reaction flask was left to evaporate slowly at room temperature. One week later, dark green plate-like crystalline material precipitated at the bottom of the flask. The product was isolated by filtration and dried in vacuo. Yield: $0.14 \mathrm{~g}$ (52\%). Anal. Calcd for 2, $\left[\mathrm{Cu}\left(\mathrm{C}_{12} \mathrm{H}_{14} \mathrm{NO}_{4}\right)_{2}\right]_{\mathrm{n}} \cdot \mathrm{nO} .\left(\mathrm{C}_{24} \mathrm{H}_{28} \mathrm{CuN}_{2} \mathrm{O}_{9}, \mathrm{M}_{\mathrm{r}} 540.04\right)$ : C, 53.38; $\mathrm{H}, 5.23 ; \mathrm{N}, 5.19$. Found: $\mathrm{C}, 53.36 ; \mathrm{H}, 5.18 ; \mathrm{N}, 5.14$. HR-ESI-MS (positive mode), calcd, for $\left\{\left[\mathrm{Cu}\left(\mathrm{C}_{12} \mathrm{H}_{14} \mathrm{NO}_{4}\right)_{2}\right]+\mathrm{H}\right\}^{+} m / z=536.1219$, found $m / z=536.1215$.

\subsection{X-ray Crystal Structure Determination}

X-ray quality crystals of 4 were grown from $\mathrm{MeOH}$. Crystals of 4 suitable for X-ray diffraction, with dimensions $0.14 \times 0.09 \times 0.05 \mathrm{~mm}$ were taken from the mother liquor and mounted at room temperature on a Bruker Kappa APEX 2 diffractometer (Bruker AXS, Madison, WI, USA), equipped with a triumph monochromator, using Mo K $\alpha$ radiation. Cell dimensions and crystal system determination were performed using 172 high $\theta$ reflections with $10^{\circ}<\theta<20^{\circ}$. Data collection ( $\varphi$ - and $\omega$ - scans) and processing (cell refinement, data reduction and numerical absorption correction based on dimensions) were performed using the SAINT and SADABS programs [23,24]. The structure was solved by the SUPERFLIP package [25]. The CRYSTALS version 14.61 build 6236 program package was used for structure refinement (full-matrix least-squares methods on $F^{2}$ ) and all subsequently remaining calculations [26]. Molecular illustrations were drawn using the CAMERON crystallographic package [27]. All non-hydrogen non-disordered atoms were anisotropically refined. All hydrogen atoms were found at their expected positions and were refined using proper riding constraints to the pivot atoms. Crystallographic details for $\mathbf{4}$ are summarized in Table S3 (Supplementary Information). Further details on the crystallographic studies as well as atomic displacement parameters are given as Supporting Information as well as in the form of cif file.

\section{Conclusions}

Two novel compounds, the Schiff base (E)-4-[(2-hydroxy-3-methoxybenzylidene)amino]butanoic acid and its $\mathrm{Cu}(\mathrm{II})$ complex were prepared in good yields and purity. The compounds have been physico-chemically and structurally characterized via elemental analysis, HR-ESI-MS, FT-IR, UV-Vis, NMR, and single crystal X-ray diffraction. The crystal structure of the produced $\mathrm{Cu}$ (II) complex reflects an one-dimensional polymeric compound. $\mathrm{The} \mathrm{Cu}(\mathrm{II})$ ion is bound to two singly deprotonated Schiff base bridging ligands forming a $\mathrm{Cu}^{\mathrm{II}} \mathrm{N}_{2} \mathrm{O}_{4}$ chelation environment, and a coordination sphere with a disordered octahedral geometry. Further investigation is underway to determine the biological activities of a library of analogue derivatives. 
Supplementary Materials: The following are available online. Table S1. Hydrogen bonds in 4. Table S2: Summary of crystal, intensity collection and refinement data for $\left[\mathrm{Cu}\left(\mathrm{C}_{12} \mathrm{H}_{14} \mathrm{NO}_{4}\right)_{2}\right]_{n} \cdot n \mathrm{O}$ (4). Figure S1. ${ }^{1} \mathrm{H}-\mathrm{NMR}$ spectrum of compound 3 in DMSO- $d_{6}$. Figure S2. ${ }^{13} \mathrm{C}-\mathrm{NMR}$ spectrum of compound 3 in DMSO- $d_{6}$. Figure S3. ${ }^{1} \mathrm{H}_{-}{ }^{1} \mathrm{H}$ COSY spectrum of compound 3 in DMSO- $d_{6}$. Figure S4. ${ }^{1} \mathrm{H}_{-}{ }^{13} \mathrm{C}$ HMBC spectrum of compound 3 in DMSO- $d_{6}$. Figure S5. ${ }^{1} \mathrm{H}^{1}{ }^{13} \mathrm{C}$ HSQC spectrum of compound 3 in DMSO- $d_{6}$. Figure S6. ${ }^{1} \mathrm{H}_{-}{ }^{1} \mathrm{H}$ NOESY spectrum of compound 3 in DMSO- $d_{6}$. Figure S7. FT-IR spectra of Schiff base 3 and complex 4. Figure S8. HRMS Spectra of the Schiff base 3. Figure S9. HRMS Spectrum of the complex 4. CCDC 2051769 (4) contains the supplementary crystallographic data for this paper. These data can be obtained free of charge via www.ccdc.cam. ac.uk/conts / retrieving.html (or from the Cambridge Crystallographic Data Centre, 12 Union Road, Cambridge CB21EZ, UK; fax: (+44)-1223-336-033; or deposit@ccde.cam.ac.uk).

Author Contributions: E.H.: inorganic synthesis, original draft preparation, methodology, metal complex structural elucidation; A.H.: X-ray crystallographic analysis; B.M.: FT-IR spectroscopic analysis; M.S.: review, editing, investigation; M.P.: review, editing, investigation; D.M.: organic synthesis, original draft preparation, methodology, ligand structural elucidation. All authors have read and agreed to the published version of the manuscript.

Funding: E. Halevas gratefully acknowledges financial support by Stavros Niarchos Foundation (SNF) through implementation of the program of Industrial Fellowships at NCSR "Demokritos" and the Foundation for Education and European Culture (IPEP) founded by Nicos and Lydia Tricha. B.M. gratefully acknowledges the financial support by the State Scholarships Foundation (IK $\checkmark$ ) through the implementation of the program of Industrial Fellowships at NCSR "Demokritos" and "Reinforcement of Postdoctoral Researchers-2nd Cycle"(MIS-5033021) (European Social Fund (ESF)-Operational Programme "Human Resources Development, Education and Lifelong Learning".

Data Availability Statement: The data presented in this study are available in this article and Supplementary Materials.

Conflicts of Interest: The authors declare no conflict of interest.

\section{References}

1. Kostova, I.; Saso, L. Advances in research of Schiff-base metal complexes as potent antioxidants. Curr. Med. Chem. 2013, 20, 4609-4632. [CrossRef]

2. Ejidike, I.P.; Ajibade, P.A. Transition metal complexes of symmetrical and asymmetrical Schiff bases as antibacterial, antifungal, antioxidant, and anticancer agents: Progress and prospects. Rev. Inorg. Chem. 2015, 35, 191-224. [CrossRef]

3. Halevas, E.; Tsave, O.; Yavropoulou, M.P.; Hatzidimitriou, A.; Yovos, J.G.; Psycharis, V.; Gabriel, C.; Salifoglou, A. Design, synthesis and characterization of novel binary $\mathrm{V}(\mathrm{V})$-Schiff base materials linked with insulin-mimetic vanadium-induced differentiation of 3T3-L1 fibroblasts to adipocytes. Structure-function correlations at the molecular level. J. Inorg. Biochem. 2015, 147, 99-115. [CrossRef] [PubMed]

4. Halevas, E.; Nday, C.M.; Chatzigeorgiou, E.; Varsamis, V.; Eleftheriadou, D.; Jackson, G.E.; Litsardakis, G.; Lazari, D.; Ypsilantis, K.; Salifoglou, A. Chitosan encapsulation of essential oil "cocktails" with well-defined binary Zn(II)-Schiff base species targeting antibacterial medicinal nanotechnology. J. Inorg. Biochem. 2017, 176, 24-37. [CrossRef] [PubMed]

5. Halevas, E.; Tsave, O.; Yavropoulou, M.; Yovos, J.G.; Hatzidimitriou, A.; Psycharis, V.; Salifoglou, A. In vitro structure-specific $\mathrm{Zn}$ (II)-induced adipogenesis and structure-function bioreactivity correlations. J. Inorg. Biochem. 2017, 177, 228-246. [CrossRef] [PubMed]

6. Shamsi, M.; Yadav, S.; Arjmand, F. Synthesis and characterization of new transition metal Cu(II), Ni(II) and Co(II) L phenylalanineDACH conjugate complexes: In vitro DNA binding, cleavage and molecular docking studies. J. Photochem. Photobiol. B 2014, 136, 1-11. [CrossRef]

7. Fattuoni, C.; Vascellari, S.; Pivetta, T. Synthesis, protonation constants and biological activity determination of amino acidsalicylaldehyde-derived Schiff bases. Amino Acids 2020, 52, 397-407. [CrossRef]

8. Gupta, K.C.; Kumar, A.S.; Lin, C.C. Polymer-supported Schiff base complexes in oxidation reactions. Coord. Chem. Rev. 2009, 253, 1923-1946. [CrossRef]

9. Abdel-Rahman, L.H.; El-Khati, R.M.; Nassr, L.A.E.; Abu-Dief, A.M. DNA binding ability mode, spectroscopic studies, hydrophobicity, and in vitro antibacterial evaluation of some new Fe(II) complexes bearing ONO donors amino acid Schiff bases. Arab. J. Chem. 2017, 10, S1835-S1846. [CrossRef]

10. Da Silva, C.M.; da Silva, D.L.; Modolo, L.V.; Alves, R.B.; de Resende, M.A.; Martins, C.V.B.; de Fátima, Â. Schiff bases: A short review of their antimicrobial activities. J. Adv. Res. 2011, 2, 1-8. [CrossRef]

11. Li, Y.; Dong, J.; Zhao, P.; Hu, P.; Yang, D.; Gao, L.; Li, L. Synthesis of amino acid Schiff base nickel (II) complexes as potential anticancer drugs in vitro. Bioinorg. Chem. Appl. 2020, 2020, 8834859. [CrossRef] [PubMed] 
12. Abu-Dief, A.M.; Mohamed, I.M.A. A review on versatile applications of transition metal complexes incorporating Schiff bases. Beni-Suef Univ. J. Basic Appl. Sci. 2015, 4, 119-133. [CrossRef] [PubMed]

13. Zou, Y.; Han, J.; Saghyan, A.S.; Mkrtchyan, A.F.; Konno, H.; Moriwaki, H.; Izawa, K.; Soloshonok, V.A. Asymmetric synthesis of tailor-made amino acids using chiral Ni(II) complexes of Schiff bases. An update of the recent literature. Molecules 2020, $25,2739$. [CrossRef]

14. Puterová-Tokárová, Z.; Mrázová, V.; Boča, R. Magnetism of novel Schiff-base copper(II) complexes derived from aminoacids. Polyhedron 2013, 61, 87-93. [CrossRef]

15. Wang, Y.-Y.; Xu, F.-Z.; Zhu, Y.-Y.; Song, B.; Luo, D.; Yu, G.; Chen, S.; Xue, W.; Wu, J. Pyrazolo[3,4-d]pyrimidine derivatives containing a Schiff base moiety as potential antiviral agents. Bioorg. Med. Chem. Lett. 2018, 28, 2979-2984. [CrossRef]

16. Jamil, D.M.; Al-Okbi, A.K.; Al-Baghdadi, S.B.; Al-Amiery, A.A.; Kadhim, A.; Gaaz, T.S.; Kadhum, A.A.H.; Mohamad, A.B. Experimental and theoretical studies of Schiff bases as corrosion inhibitors. Chem. Cent. J. 2018, 12, 7. [CrossRef]

17. Mobinikhaledi, A.; Jabbarpour, M.; Hamta, A. Synthesis of some novel and biologically active Schiff bases bearing a 1,3,4thiadiazole moiety under acidic and PTC conditions. J. Chil. Chem. Soc. 2011, 56, 812-814. [CrossRef]

18. Galić, N.; Cimerman, Z.; Tomišić, V. Spectrometric study of tautomeric and protonation equilibria of o-vanillin Schiff base derivatives and their complexes with Cu(II). Spectrochim. Acta A Mol. Biomol. Spectrosc. 2008, 71, 1274-1280. [CrossRef]

19. Pis-Diez, R.; Echeverria, G.A.; Piro, O.E.; Jios, J.L. Parajón-Costa, B.S. A structural, spectroscopic and theoretical study of an o-vanillin Schiff base derivative involved in enol-imine and keto-amine tautomerism. New J. Chem. 2016, 40, 2730-2740. [CrossRef]

20. Muche, S.; Harms, K.; Biernasiuk, A.; Malm, A.; Popiołek, Ł.; Hordyjewska, A.; Olszewska, A.; Hołyńska, M. New Pd(II) Schiff base complexes derived from ortho-vanillin and L-tyrosine or L-glutamic acid: Synthesis, characterization, crystal structures and biological properties. Polyhedron 2018, 151, 465-477. [CrossRef]

21. Halevas, E.; Pekou, A.; Papi, R.; Mavroidi, B.; Hatzidimitriou, A.G.; Zahariou, G.; Litsardakis, G.; Sagnou, M.; Pelecanou, M.; Pantazaki, A.A. Synthesis, physicochemical characterization and biological properties of two novel Cu(II) complexes based on natural products curcumin and quercetin. J. Inorg. Biochem. 2020, 208, 111083. [CrossRef] [PubMed]

22. Munde, A.S.; Jagdale, A.N.; Jadhav, S.M.; Chondhekar, T.K. Synthesis, characterization and thermal study of some transition metal complexes of an asymmetrical tetradentate Schiff base ligand. J. Serb. Chem. Soc. 2010, 75, 349-359. [CrossRef]

23. Bruker Analytical X-Ray Systems, Inc. Apex2, Version 2 User Manual: M86-E01078; Bruker Analytical X-Ray Systems, Inc.: Madison, WI, USA, 2006.

24. Siemens Industrial Automation, Inc. SADABS: Area-Detector Absorption Correction; Siemens Industrial Automation, Inc.: Madison, WI, USA, 1996.

25. Betteridge, P.W.; Carruthers, J.R.; Cooper, R.I.; Prout, K.; Watkin, D.J. CRYSTALS version 12: Software for guided crystal structure analysis. J. Appl. Cryst. 2003, 36, 1487. [CrossRef]

26. Palatinus, L.; Chapuis, G. SUPERFLIP-a computer program for the solution of crystal structures by charge flipping in arbitrary dimensions. Appl. Cryst. 2007, 40, 786-790. [CrossRef]

27. Watkin, D.J.; Prout, C.K.; Pearce, L.J. CAMERON; Chemical Crystallography Laboratory: Oxford, UK, 1996. 